\title{
Correction to: Expectations and psychological issues before genetic counseling: analysis of distress determinant factors
}

Zelmira Ballatore ${ }^{1 *}$, Raffaella Bracci ${ }^{2}$, Elena Maccaroni ${ }^{1}$, Lucia Svarca ${ }^{3}$, Francesca Bianchi ${ }^{1}$, Laura Belvederesi ${ }^{1}$, Cristiana Brugiati ${ }^{1}$, Silvia Pagliaretta ${ }^{1}$, Alberto Murrone ${ }^{1}$, Federica Bini ${ }^{1}$, Mirco Pistelli ${ }^{1}$, Giulia Ricci ${ }^{1}$ and Rossana Berardi ${ }^{1}$

\section{Correction to: Hered Cancer Clin Pract 2020, 18: 10 https://doi.org/10.1186/s13053-020-00142-1}

Following publication of the original article [1], the authors identified an error in the author name of Cristiana Brugiati.

The incorrect author name is: Cristiana Bruciati

The correct author name is: Cristiana Brugiati

The author group has been updated above and the original article [1] has been corrected.

\begin{abstract}
Author details
${ }^{1}$ Clinica Oncologica, Azienda Ospedaliero Universitaria Ospedali Riuniti di Ancona Umberto I G M Lancisi G Salesi, Ancona, Italy. ${ }^{2}$ Oncologia, Azienda Ospedaliera Ospedali Riuniti Marche Nord, Presidio Santa Croce, Fano, Italy. ${ }^{3}$ Neuropsichiatria Infantile, Azienda Ospedaliero Universitaria Ospedali Riuniti di Ancona Umberto I G M Lancisi G Salesi, Ancona, Italy.
\end{abstract}

Published online: 19 May 2020

\section{Reference}

1. Ballatore Z, Bracci R, Maccaroni E, et al. Expectations and psychological issues

before genetic counseling: analysis of distress determinant factors. Hered Cancer Clin Pract. 2020;18:10 https:/doi.org/10.1186/s13053-020-00142-1.

The original article can be found online at https://doi.org/10.1186/s13053020-00142-1.

*Correspondence: zelmira.ballatore@ospedaliriuniti.marche.it

${ }^{1}$ Clinica Oncologica, Azienda Ospedaliero Universitaria Ospedali Riuniti di Ancona Umberto I G M Lancisi G Salesi, Ancona, Italy

Full list of author information is available at the end of the article

C C The Author(s). 2020 Open Access This article is licensed under a Creative Commons Attribution 4.0 International License, which permits use, sharing, adaptation, distribution and reproduction in any medium or format, as long as you give appropriate credit to the original author(s) and the source, provide a link to the Creative Commons licence, and indicate if changes were made. The images or other third party material in this article are included in the article's Creative Commons licence, unless indicated otherwise in a credit line to the material. If material is not included in the article's Creative Commons licence and your intended use is not permitted by statutory regulation or exceeds the permitted use, you will need to obtain permission directly from the copyright holder. To view a copy of this licence, visit http://creativecommons.org/licenses/by/4.0/ The Creative Commons Public Domain Dedication waiver (http://creativecommons.org/publicdomain/zero/1.0/) applies to the data made available in this article, unless otherwise stated in a credit line to the data. 